\title{
Leaf Litter Decomposition and Nutrient Release of Three Native Tree Species in a Drained Tropical Peatland in Riau, Indonesia
}

\author{
Ahmad Junaedi ${ }^{*}$, Nina Mindawati ${ }^{2}$, Avry Pribadi' ${ }^{\prime}$ Suryo Hardiwinoto ${ }^{3}$ \\ ${ }^{1}$ Research Institute for Fiber Technology of Forest Plant Species, The Ministry of Environment and Forestry, Kampar, Indonesia \\ ${ }^{2}$ Forest Research and Development Center, Bogor, Indonesia \\ ${ }^{3}$ Forest Faculty, Gadjah Mada University, Yogyakarta, Indonesia
}

ARTICLE INFO

Article history:

Received October 13, 2021

Received in revised form December 1, 2021

Accepted December 16, 2021

\section{KEYWORDS:}

litter decomposition,

nutrient release,

native tree species,

lignin content

\begin{abstract}
The decomposition and its nutrient release were the key ecological process that had a broad role in the forest ecosystem. This study aimed to investigate the leaf litter decomposition rate and its nutrient release of three native tree species of tropical peat swamp forest, namely Macaranga pruinosa, Macaranga gigantea, and Cratoxylum arborescens and one exotic species i.e Acacia crassicarpa. The decomposition and nutrient release were monitored in an experimental plot using litter bag technique. The initial litter quality of each litter and micro-environment properties were also observed. The result showed that the decomposition and its nutrient release were insignificantly different among native tree species and also between native species and Acacia crasssicarpa. The litter decomposition of all tree species was slow; with the range of $k$ was $0.98-1.19$ year ${ }^{-1}$. However, the $P$ and $K$ release from the decomposition of native species litter after four months of incubation were quickly, ranging $70-74 \%$ and $88-93 \%$. We were suggested that the high of lignin content in the leaf litter (36-39\%) was the main factor that made slow decomposition. These findings could be used as one of the tools in tree species selection for peat swamp forest rehabilitation.
\end{abstract}

\section{Introduction}

The degradation of peat swamp forests (PSFs) in Indonesia is in serious rate. For instance, the remain of pristine PSFs in two largest area of PSFs in Indonesia (Kalimantan and Sumatra) was less than $4 \%$, while the area of PSF with varying degree of degradation was remain 37\% (Miettinen and Liew 2010). This fact was often connected to the disaster of fire and hazes which had significant impact on economic value. As the example, the economic losing value due to fire and haze disaster of peat land in Indonesia at 2013 and 2019 were USD 1.49 billion and USD 5.2 billion, respectively (Gultom et al. 2016; Worldbank 2019). Furthermore, another impact of this disaster in regional and global level is greenhouse gasses release (especially $\mathrm{CO}_{2}$ ) which drives climate change. Carbon emission from peat fire in Indonesia is relatively high, which was in 2015 only could reach about 0.002 Gtonnes (Setyawati and Suwarsono 2018). Totally,

\footnotetext{
* Corresponding Author

E-mail Address: ajunaedi81@yahoo.co.id
}

the Indonesia's peat fire contribution to global carbon and methane emission were 8 and 23 percent (Charles 2019).

Degradation and deforestation of PSFs in Indonesia must be halted by increasing the rehabilitation through tree plantation activity. The use of native tree species in peatland rehabilitation can be promoted due to some previous studies showed a lot of benefits, particularly in biodiversity and ecosystem service term (Löf et al. 2019; Nurulita et al. 2016).

We selected three native tree species of PSFs with local name mahang (Macaranga pruinosa), skubung (Macaranga gigantea) and geronggang (Cratoxylum arborescens) for the deeper evaluation in purpose for peatland restoration. Those native tree are pioneer species which naturally occurred in peat forest and had better survivorship than an exotic tree species namely Acacia crassicarpa (Suhartati et al. 2012; Junaedi 2018). However, generally little was known about the species traits, thus to promote those species for peatland rehabilitation or other purpose more scientific information is required. 
Present study focused to understand the leaf litter decomposition and its nutrient release of the three native tree species as the important ecological indexes. It was well known that its understanding is important due to decomposition is a key ecological process that has broad role in forest ecosystem such as ecosystem sustainability and productivity, carbon and nutrient cycling, soil process and properties; diversity and stability of ecological community and forest regeneration (Versini et al. 2014; Das and Mondal 2016; Penner and Frank 2019). Indeed, it was suggested that $30-60 \%$ of annual nutrients requirement of tree in forest was provided by this ecological process (Boyle 2005). Moreover, little is known about the litter decomposition insight of native tree species of PSFs, thus this study also will be useful to reduce this gap.

Litter decomposition is controlled by some factors such as litter chemical composition (litter quality), climate, nutrient availability, composition of soil organisms and site-specific factors (Berg and Mcclaugherty 2014; Penner and Frank 2019). Among those factors, the difference of tree species can make the difference on litter quality, nutrient availability and site-specific factors (Aponte et al. 2012; Wright et al. 2013; Peng et al. 2019). For more detail, it was important to study the relationship between the litter decomposition and litter quality and also micro-site characteristic under stands (soil properties and microclimate). Therefore, the aims of the study were: (1) to investigate chemical component (litter quality) in initial leaf litter of the three native tree species, (2) to investigate micro-environment properties under the three native tree species and (3) to explore leaf litter decomposition and its nutrient release of the three native tree species associated with litter quality and micro-environment.

\section{Materials and Methods}

\subsection{Study Site}

The study was conducted in an experimental plot; located in a community forest at Lubuk Ogong Village, Pelalawan District, Riau Province, Indonesia (101 ${ }^{\circ} 41^{\prime} 06^{\prime \prime}-$ $101^{\circ} 41^{\prime} 10^{\prime \prime} \mathrm{E}, 0^{\circ} 19^{\prime} 42^{\prime \prime}-0^{\circ} 19^{\prime} 48^{\prime \prime} \mathrm{N}$, elevation of $12 \mathrm{~m}$ asl). The study site is characterized by a equatorial climate or type A based on Schmidt-Ferguson system, with the range of daily temperature was $21-32^{\circ} \mathrm{C}$ and mean annual rain fall was $2,500-3,000 \mathrm{~mm}$; a peat soil (histosol) with maturity was dominated by fibrichemic;and has been drained with the depth of water table variation was $20-135 \mathrm{~cm}$ (Husnain et al. 2014; Husnain et al. 2017; Junaedi 2018).

\subsection{Litter Decomposition Experiment}

In the beginning, the experiment plot was established in purpose to observe the growth performance of three native tree species of peatland. Tree species was the single treatment in this experimental plot, which was consisted of four species. These tree species consist of three native species/NS (Macaranga pruinosa/mahang, Cratoxylum arborescens/geronggang, and Macaranga gigantea/ skubung) and as the comparison also including one exotic tree species (Acacia crassicarpa/krassikarpa). All species were planted in similar spacing $(2 \times 3$ $\mathrm{m})$. The plantation was arranged in the field based on a randomized complete block design with five replications, thus each species had five subplots or 20 subplots in total ( 4 species $x 5$ replication). Detailed information about this plot experiment also can be seen in (Junaedi 2018). Followed this experimental design; the study of decomposition was done during six months, when the tree age was about 2.5-3 years old. The data of growth average for all studied species at 2.5 years old is shown in Table 1 .

The decomposition rate and nutrient release were measured via litter bag technique. The measurement only focused to leaf litter, but it was representative due to the fraction of leaf litter mass in all studied species were dominant i.e. more than $89 \%$ (Junaedi et al. 2020). Litters from all studied species were collected as freshly fallen leaves and straw from the peat surface (Guo et al. 2019). Most of the collected litter then oven dried for about $48 \mathrm{~h}$ at $70^{\circ} \mathrm{C}$ (until constant weight). The leaf litters of each individual species were mixed to obtain a uniform mixture prior being placed in the litterbags. Twenty grams of oven dried leaf litter of all the species then placed to the 25 x $25 \mathrm{~cm}$ nylon plastic bag with about $2.0 \mathrm{~mm}$ mesh. However, for the litter of skubung, litter must be cutted in to smaller pieces before being placed in the litterbags due to had size that bigger than litterbag size (Hoyos-Santillan et al. 2015).

Partly of the collected litter was send to the Laboratory of soil and plant SEAMEO-BIOTROP and Laboratory of woodchemistry, Faculty of Forestry, UGM for analyses the chemycal content of initial litter. These analyses were runned for content of total organic $\mathrm{C}$ (Walkey and Black method); total $\mathrm{N}$ (Kjeldahl method), total $\mathrm{P}$ and $\mathrm{K}$ (extract method $\mathrm{HCl}$ 25\%); water-soluble organic matter/WSOM (ASTM 
Table 1. The growth characteristics of all studied species at 2.5 years old (Junaedi 2018)

\begin{tabular}{llll}
\hline Tree Species & Survivorship $(\%)$ & Height $(\mathrm{m})$ & $\mathrm{DBH}(\mathrm{cm})$ \\
\hline Mahang (Macarangapruinosa) & $91.2 \pm 3.35$ & $5.8 \pm 0.30$ & $6.6 \pm 0.61$ \\
Skubung (Macarangagigantea) & $68.8 \pm 16.83$ & $3.3 \pm 0.55$ & $5.5 \pm 0.40$ \\
Geronggang (Cratoxylumarborescens) & $88.8 \pm 3.35$ & $5.7 \pm 0.34$ & $6.4 \pm 0.25$ \\
Krassikarpa (Acacia crassicarpa) & $64.8 \pm 14.81$ & $13.8 \pm 1.03$ & $14.0 \pm 0.80$ \\
\hline
\end{tabular}

D-1110-1984 method), cellulose (ASTM-D1103-1984 method), lignin (ASTM-D-1106-1984 method) and polyphenol (Folin-Ciolcateu method).

Litterbags of each studied species were distributed to the field according to experimental design that was established. Five litterbags were placed at forest floor (under the stand) for each subplot, thus in total there were 100 litterbags ( 5 litterbags x 20 subplots) that was deployed. One Litterbag in each subplot was collected five times i.e. after one, two, three, four and six incubation months (Dale et al. 2015; Das and Mondal 2016). In laboratory, litterbags were cleaned to remove exogenous materials and then be weighed after oven drying at $70^{\circ} \mathrm{C} 48 \mathrm{~h}$. In order to calculate nutrient release of leaf litter decomposition, nutrient content $(\mathrm{N}, \mathrm{P}$, and $\mathrm{K})$ in litters that was collected after four incubation months were analyzed in Soil and Plant laboratory of Research Division of PT. Sarana Inti Pratama (SAIN) in Pekanbaru, Riau. Total N content was analyzed with Kjeldahl method, while total $P$ and $\mathrm{K}$ were extracted with $25 \% \mathrm{HCl}$.

\subsection{Micro-Environment around Litter}

Soil samples were collected when the age of all tree species were 2.5 years old using a hoe under each tree species for a depth about 0-20 cm. Samples were collected from five points under each tree and combined to obtain a composite sample. This work was undertaken in three replications for each species, thus each tree species has three composite soil samples (12 composite soil samples in total). Samples were sealed in plastic bags and transported to the laboratory. The soil samples were analyzed in the laboratory of SAIN Pekanbaru, Riau. The analyses included $\mathrm{pH}$ using $\mathrm{pH}$ meter, total $\mathrm{C}$ using colorimeter method, total $\mathrm{N}$ using Kjeldahl method, available $\mathrm{P}$ using Bray II method, base cations ( $\mathrm{K}, \mathrm{Mg}, \mathrm{Ca}$, and $\mathrm{Na}$ ) and cation exchange capacity using $\mathrm{NH}_{4} \mathrm{OAc}(\mathrm{pH}$ 7.0) extraction method.

Due to the limitedness of cost and man power, microclimate around litter was measured only in two times, i.e. in relatively dry season (September 2013) and relatively wet season (November 2013). The observation chosen two variables which was suggested as the most important of litter decomposition determinant in local scale, i.e. temperature and moisture around litter (Petraglia et al. 2019). Litter temperature (LM), litter moisture (LM) and below litter temperature (BLT) were monitored hourly during 08.00 AM-16.00 PM. Temperature and moisture were observed by portable temperature and moisture probe.

\subsection{The Calculations of Decomposition and Nutrient Release Rate}

The litterbags of mahang and geronggang at six months after incubation were incomplete and lead to the miss data. Based on the method in (Attignon et al. 2004), the missing data were filled prior to calculate. The remaining mass of litter, decomposition rate and nutrients release then becalculated. The remaining mass of litter was expressed in percentage of initial litter mass. Decomposition rate was expressed by the percentage of mass loss and theconstant of decay rate $(\mathrm{k})$ was calculated using the equation that was given by (Olson 1963) and (Berg and Mcclaugherty 2014): $W_{t}=$ Wo.e-kt, where $W_{o}$ and $W_{t}$ are the initial and remaining (at time $\mathrm{t}$ ) weight of oven-dry leaves respectively; $t$ is the elapsedtime (year); $\mathrm{e}$ is the base of natural logarithm and $\mathrm{k}$ is the decay constant $\left(\right.$ years $^{-1}$ ). Theestimation of time periods to $50 \%$ and 95\% litter mass loss $\left(t_{50}\right.$ and $\left.t_{95}\right)$ were calculated with equation: $\mathrm{t}_{50}=0.693 / \mathrm{k}$ and $\mathrm{t}_{95}=2.9957 / \mathrm{k}$ (Lalramliani et al. 2016). Furthermore, nutrient release rate (Nr) from leaf decomposition was calculated using the equation: $\mathrm{Nr}=\left(\left(\mathrm{W}_{0} \cdot \mathrm{N}_{0}\right)-\left(\mathrm{W}_{\mathrm{t}} \cdot \mathrm{N}_{\mathrm{t}}\right)\right) /\left(\mathrm{W}_{0} \cdot \mathrm{N}_{0}\right)$ (Peng et al. 2019); where $W_{0}$ and $N_{0}$ are the initial litter dry mass and the initial concentration of $\mathrm{N}, \mathrm{P}$ or $\mathrm{K}$ in litter, respectively; $\mathrm{W}_{t}$ and $\mathrm{N}_{t}$ are the litter dry mass after $\mathrm{t}$ months incubation and the concentration of $\mathrm{N}, \mathrm{P}$ or $\mathrm{K}$ in litter after $t$ months incubation.

\subsection{Data Analysis}

The data of litter mass loss, $\mathrm{k}$ and rate of immobilized $\mathrm{N}$ were inhomogeneous therefore must be transformed to the $\log (\mathrm{x}+1), \log (\mathrm{x}+1)$ and $\mathrm{x}^{0.25}$ form (respectively), prior to analysis. One way analysis of variance (ANOVA) was performed to identify the difference of: chemical composition of initial leaf litter, soil properties, microclimate, percentage of mass loss, $\mathrm{k}, \mathrm{t}_{50}, \mathrm{t}_{95}$ and $\mathrm{Nr}$. When the result of the ANOVA was significant, Duncan's multiple range tests was used to determine significant difference between pairs of tree species treatments. Pearson correlation and linear regression analysis were performed to assess the effect 
Table 2. The chemical composition in initial leaf litter of the studied species

\begin{tabular}{lllll}
\hline Variables (units) & Mahang & Geronggang & Skubung & Krassikarpa \\
\hline Total C (\%) & $37.49 \pm 0.51^{\mathrm{b}}$ & $33.87 \pm 0.19^{\mathrm{a}}$ & $38.43 \pm 0.47^{\mathrm{b}}$ & $34.92 \pm 0.13^{\mathrm{a}}$ \\
Total N (\%) & $0.94 \pm 0.01^{\mathrm{ab}}$ & $0.93 \pm 0.02^{\mathrm{ab}}$ & $0.99 \pm 0.02^{\mathrm{b}}$ & $0.89 \pm 0.01^{\mathrm{a}}$ \\
Total P (\%) & $0.14 \pm 0.01^{\mathrm{a}}$ & $0.17 \pm 0.00^{\mathrm{a}}$ & $0.14 \pm 0.00^{\mathrm{a}}$ & $0.14 \pm 0.01^{\mathrm{a}}$ \\
Total K (\%) & $0.85 \pm 0.00^{\mathrm{a}}$ & $0.88 \pm 0.01^{\mathrm{a}}$ & $1.01 \pm 0.02^{\mathrm{b}}$ & $0.89 \pm 0.01^{\mathrm{a}}$ \\
C/N & $39.78 \pm 0.48^{\mathrm{a}}$ & $36.48 \pm 0.61^{\mathrm{a}}$ & $39.02 \pm 1.39^{\mathrm{a}}$ & $39.40 \pm 0.62^{\mathrm{a}}$ \\
Water-soluble organic matter (\%) & $19.17 \pm 1.88^{\mathrm{a}}$ & $15.81 \pm 0.38^{\mathrm{a}}$ & $14.63 \pm 0.88^{\mathrm{a}}$ & $16.60 \pm 0.27^{\mathrm{a}}$ \\
Cellulose (\%) & $32.85 \pm 3.61^{\mathrm{a}}$ & $36.69 \pm 0.50^{\mathrm{a}}$ & $39.26 \pm 0.16^{\mathrm{a}}$ & $47.96 \pm 1.19^{\mathrm{b}}$ \\
Polyphenols (mg GAE/g dry weight) & $2.57 \pm 0.43^{\mathrm{b}}$ & $0.83 \pm 0.26^{\mathrm{a}}$ & $1.30 \pm 0.61^{\mathrm{ab}}$ & $0.50 \pm 0.06^{\mathrm{a}}$ \\
Lignin (\%) & $36.12 \pm 0.84^{\mathrm{a}}$ & $38.23 \pm 0.42^{\mathrm{a}}$ & $39.23 \pm 1.46^{\mathrm{a}}$ & $33.83 \pm 2.25^{\mathrm{a}}$ \\
Lignin/N & $38.29 \pm 0.86^{\mathrm{a}}$ & $41.12 \pm 0.22^{\mathrm{a}}$ & $39.84 \pm 2.09^{\mathrm{a}}$ & $38.19 \pm 2.78^{\mathrm{a}}$
\end{tabular}

Means within the same row followed by the different letters are significantly different $(\mathrm{p}<0.05)$

Table 3. Soil properties under the stands of studied species stands at 2.5 years old

\begin{tabular}{|c|c|c|c|c|}
\hline Variables (units) & Mahang & Geronggang & Skubung & Krassikarpa \\
\hline$\overline{\mathrm{pH} \mathrm{H}_{2} \mathrm{O}^{\mathrm{ns}}}$ & $2.96 \pm 0.07$ & $2.96 \pm 0.07$ & $2.93 \pm 0.07$ & $3.07 \pm 0.07$ \\
\hline Total $^{2}{ }^{\text {ns }}(\%)$ & $43.43 \pm 0.62$ & $44.07 \pm 0.12$ & $43.33 \pm 0.65$ & $44.50 \pm 0.81$ \\
\hline Total Nns (\%) & $1.65 \pm 0.08$ & $1.66 \pm 0.07$ & $1.74 \pm 0.05$ & $1.75 \pm 0.05$ \\
\hline $\mathrm{C} / \mathrm{N}^{\mathrm{ns}}$ & $26.45 \pm 1.28$ & $26.58 \pm 1.11$ & $24.89 \pm 0.78$ & $25.55 \pm 1.20$ \\
\hline Available Pns (ppm) & $37.86 \pm 3.81$ & $30.37 \pm 0.99$ & $29.7 \pm 4.09$ & $38.97 \pm 4.08$ \\
\hline Exchangeable Ca $^{\text {ns }}(\mathrm{me} / 100 \mathrm{~g}$ ) & $6.81 \pm 1.71$ & $6.28 \pm 1.32$ & $3.92 \pm 1.24$ & $3.64 \pm 1.62$ \\
\hline Exchangeable $\mathrm{Mg}^{\text {ns }}$ (me/100 g) & $1.67 \pm 0.14$ & $2.20 \pm 0.30$ & $1.67 \pm 0.20$ & $2.19 \pm 0.35$ \\
\hline Exchangeable $\mathrm{K}^{\mathrm{s}}(\mathrm{me} / 100 \mathrm{~g})$ & $0.44 \pm 0.04 \mathrm{ab}$ & $0.41 \pm 0.02 \mathrm{~b}$ & $0.53 \pm 0.04 a$ & $0.54 \pm 0.04 a$ \\
\hline Exchangeable $\mathrm{Na}^{\text {ns }}(\mathrm{me} / 100 \mathrm{~g}$ ) & $0.67 \pm 0.003$ & $0.62 \pm 0.08$ & $0.69 \pm 0.05$ & $0.75 \pm 0.12$ \\
\hline Cation exchange capacityns (me/100 g) & $158.00 \pm 4.33$ & $164.33 \pm 7.88$ & $150.00 \pm 1.53$ & $159.67 \pm 2.91$ \\
\hline
\end{tabular}

$s$ = Signifcantly different $(\mathrm{p}<0.05)$, ${ }^{\text {ns }}=$ not significantly different $(\mathrm{p}>0.05)$, means within the same row followed by the different letters are significantly different $(\mathrm{p}<0.05)$

of initial litter quality and micro-environment (soil properties and microclimate) to the decomposition.

\section{Results}

\subsection{Chemical Composition of Initial Leaf Litter}

Content of total C in leaf litter of two native species/ NS (mahang and skubung) was significantly higher $(\mathrm{p}<0.05)$ than that in the exotic species krassikarpa (ES) and one remain NS (geronggang). The total N content in NS generally was higher than that in ES, but the significant difference ( $\mathrm{p}<0.05$ ) only revealed between skubung and krassikarpa (Table 2). The content of cellulose in ES was significantly higher ( $p$ $<0.05$ ) than that in all NS, while the content among NS wererelatively similar. Initial litter of Mahang had highest polyphenol, and significantly $(\mathrm{p}<0.05)$ higher than that in geronggang and krassikarpa. The content of total $\mathrm{P}$, total $\mathrm{K}$, lignin and water-soluble organic matter (WSOM) among all studied species (SS) were insignificantly $(\mathrm{p}>0.05)$ different. $\mathrm{C} / \mathrm{N}$ and lignin $/ \mathrm{N}$ quotients in the leaf litter of SS were insignificantly different ( $p>0.05)$.

\subsection{Micro-Environment}

Soil properties generally were insignificantly different ( $p>0.05$ ) among NS, also between NS and
ES (Table 3). The soil under all species has low $\mathrm{pH}$ (extremely acid), high total $\mathrm{N}$, low available $\mathrm{P}$ and low base cations.

Microclimate around litter was insignificantly varied ( $p>0.05$ ) under SS stands, except for litter moister in dry season. The moister litter under ES stand was significantly higher $(p<0.05)$ than that under NS. Generally, litter moister in all SS (NS and ES) were relatively high (above 70\%), despite in dry season, except in skubung litter (Table 4).

\subsection{Litter Decomposition and Its Nutrient Release}

Litter mass loss and constants of decay rate $(\mathrm{k})$ after six months of incubation in all SS were insignificantly different $(p>0.05)$ (Table 5, Figure 1A). The range of $k$ of all NS was $0.98-1.19$ year $^{-1}$, while $\mathrm{k}$ of ES was 0.98 (Figure 1A). Furthermore, the required time for $50 \%$ and 95\% decay were fastest in geronggang litter $\left(t_{50}\right.$ $=0.63$ years and $t_{95}=2.71$ years), but insignificantly different $(p>0.05)$ than that in other NS and ES (Figure 1B).

After four months of incubation, the percentage of $\mathrm{P}$ and $\mathrm{K}$ released from decomposition of NS leaf litter reached 70.1-73.8\% and 89.5-93.1\%, respectively (Figure 2). This P release was insignificantly different among NS, but significantly slower $(p>0.05)$ than 
Table 4. Microclimate around litter under studied species stands

\begin{tabular}{lllll}
\hline & Mahang & Geronggang & Skubung & Krassikarpa \\
\hline Dry season: & & & & \\
$\quad$ Litter moister $(\%)$ & $71.26 \pm 10.20^{\mathrm{b}}$ & $79.78 \pm 8.07^{\mathrm{b}}$ & $56.04 \pm 5.33^{\mathrm{c}}$ & $91.24 \pm 7.42^{\mathrm{a}}$ \\
Litter temperature $\left({ }^{\circ} \mathrm{C}\right)$ & $29.12 \pm 0.84^{\mathrm{a}}$ & $28.57 \pm 0.52^{\mathrm{a}}$ & $29.03 \pm 0.72^{\mathrm{a}}$ & $28.92 \pm 0.73^{\mathrm{a}}$ \\
Below litter temperature $\left({ }^{\circ} \mathrm{C}\right)$ & $28.50 \pm 0.25^{\mathrm{a}}$ & $28.40 \pm 0.35^{\mathrm{a}}$ & $28.57 \pm 0.68^{\mathrm{a}}$ & $28.78 \pm 0.17^{\mathrm{a}}$ \\
Wet season: & & & & \\
Litter moister $(\%)$ & $88.44 \pm 0.66^{\mathrm{a}}$ & $89.41 \pm 1.46^{\mathrm{a}}$ & $87.03 \pm 1.55^{\mathrm{a}}$ & $91.79 \pm 1.38^{\mathrm{a}}$ \\
Litter temperature $\left({ }^{\circ} \mathrm{C}\right)$ & $27.78 \pm 0.26^{\mathrm{a}}$ & $27.33 \pm 0.24^{\mathrm{a}}$ & $27.98 \pm 0.67^{\mathrm{a}}$ & $28.08 \pm 0.19^{\mathrm{a}}$ \\
Below litter temperature $\left({ }^{\circ} \mathrm{C}\right)$ & $27.67 \pm 0.22^{\mathrm{a}}$ & $27.30 \pm 0.15^{\mathrm{a}}$ & $27.68 \pm 0.34^{\mathrm{a}}$ & $28.0 \pm 0.19^{\mathrm{a}}$ \\
\hline
\end{tabular}

Table 5. Change in litter mass loss (\%) over time (months) of studied species

\begin{tabular}{cllll}
\hline Months after incubation & Mahang & Geronggang & Skubung & Krassikarpa \\
\hline 1 & $4.75 \pm 0.92^{\mathrm{b}}$ & $4.90 \pm 1.24^{\mathrm{b}}$ & $2.90 \pm 1.20^{\mathrm{b}}$ & $15.2 \pm 1.05^{\mathrm{a}}$ \\
2 & $15.12 \pm 1.85^{\mathrm{b}}$ & $12.95 \pm 1.75^{\mathrm{b}}$ & $6.10 \pm 1.30^{\mathrm{c}}$ & $19.73 \pm 1.69^{\mathrm{a}}$ \\
3 & $20.91 \pm 3.15^{\mathrm{b}}$ & $18.70 \pm 1.29^{\mathrm{bc}}$ & $11.12 \pm 2.28^{\mathrm{c}}$ & $29.92 \pm 3.37^{\mathrm{a}}$ \\
4 & $28.87 \pm 4.69^{\mathrm{a}}$ & $26.00 \pm 2.99^{\mathrm{a}}$ & $14.00 \pm 2.56^{\mathrm{b}}$ & $33.50 \pm 3.19^{\mathrm{a}}$ \\
6 & $41.50 \pm 4.12^{\mathrm{a}}$ & $44.04 \pm 5.51^{\mathrm{a}}$ & $39.75 \pm 4.73^{\mathrm{a}}$ & $39.40 \pm 1.87^{\mathrm{a}}$ \\
\hline
\end{tabular}
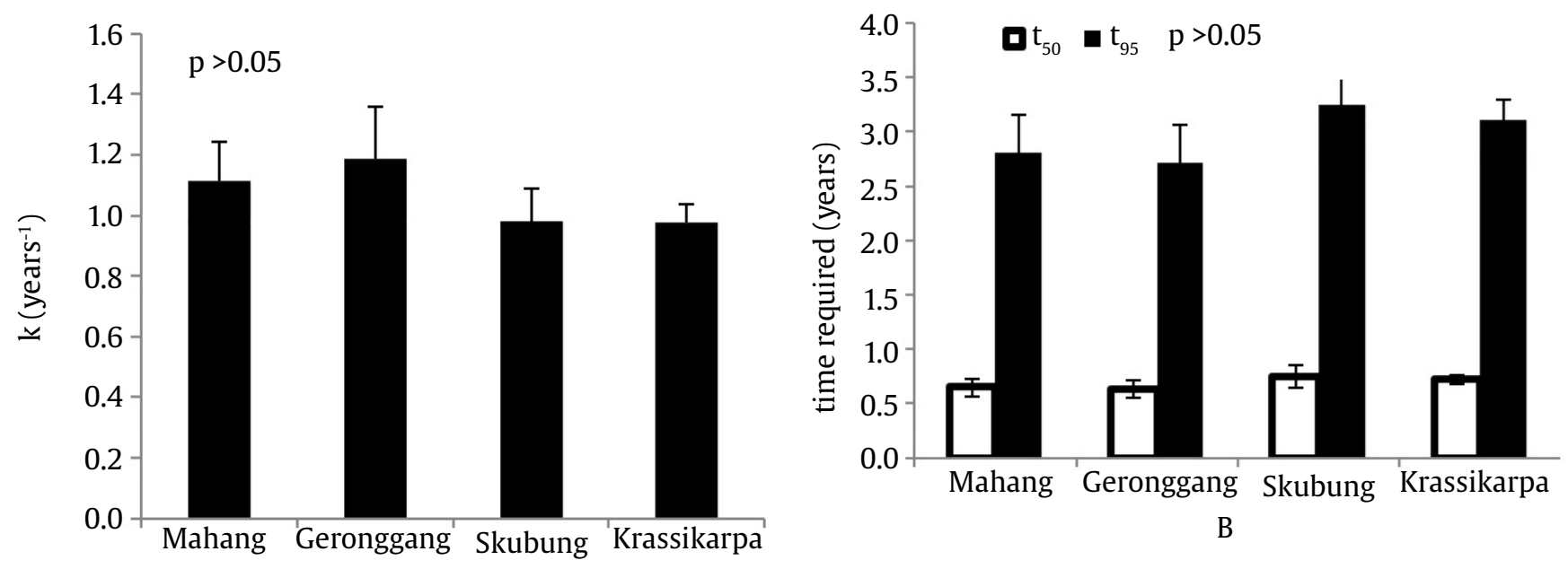

A

Figure 1. Decomposition rate constants (A) and time required for 50\% $\left(t_{50}\right)$ and $95 \%\left(t_{95}\right)$ decomposition (B) in different studied species
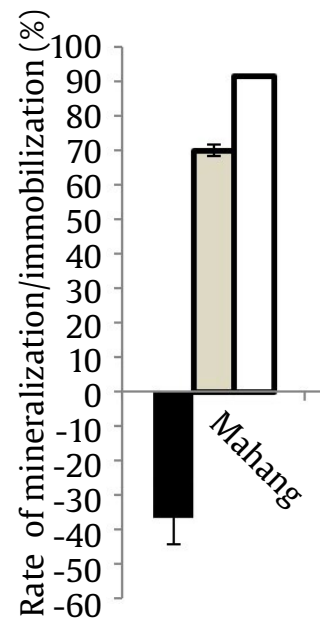

- $\mathrm{N}$ 口 $\mathrm{P} \mathrm{K} \mathrm{p}>0.05$

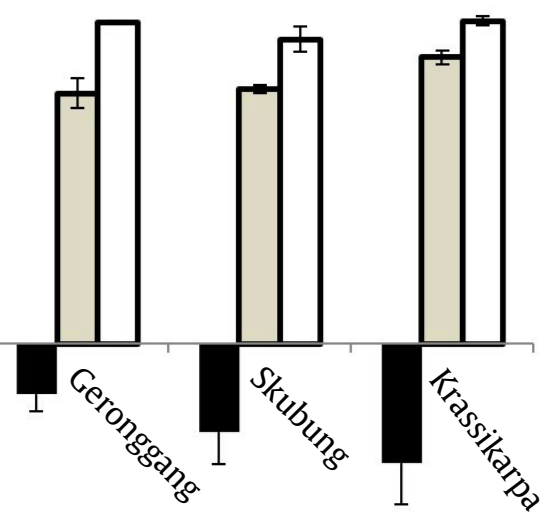

Figure 2. The percentage of $\mathrm{N}$ immobilization, $\mathrm{P}$ and $\mathrm{K}$ released from leaf litter decomposition after four months incubation (negative value for immobilization and positive value for mineralization) that of ES with $\mathrm{P}$ release $82.6 \%$. $\mathrm{K}$ released was insignificantly different between all NS and ES (Figure 4). Different with $\mathrm{P}$ and $\mathrm{K}, \mathrm{N}$ in all litters of SS were immobilized. Range of this immobilized $\mathrm{N}$ of NS was $14.5-25.6 \%$ and insignificantly different $(\mathrm{p}>0.05)$ among them and with ES.

\subsection{Correlation between Decomposition and Litter Quality and Micro-environment}

All variables of litter quality were insignificantly correlated $(p>0.05)$ with decomposition rate $(k)$ (Table 6). The insignificant correlation $(p>0.05)$ also showed by the relationship between all variable of micro-environment and $\mathrm{k}$ (Table 7). 
Table 6. Correlation coefficients between $k$ and chemical composition of initial litter $(p>0.05)$

\begin{tabular}{llllllccccc}
\hline \multirow{2}{*}{ k $\left(\right.$ year $\left.^{1}\right)$} & $\mathrm{C}$ & $\mathrm{N}$ & $\mathrm{P}$ & $\mathrm{K}$ & $\mathrm{C} / \mathrm{N}$ & WSOM & Cellulose & Polyphenol & Lignin & Lignin $/ \mathrm{N}$ \\
\cline { 2 - 10 } & -0.45 & 0.55 & 0.21 & 0.46 & 0.05 & 0.52 & -0.13 & 0.08 & -0.01 & 0.36 \\
\hline
\end{tabular}

Table 7. Correlation coefficients between $\mathrm{k}$ and micro-environment $(\mathrm{p}>0.05)$

\begin{tabular}{|c|c|c|c|c|c|c|c|c|c|c|c|c|c|}
\hline \multirow{2}{*}{$\mathrm{k}\left(\right.$ year $\left.^{1}\right)$} & $\mathrm{pH}$ & $C$ & $\mathrm{~N}$ & $\mathrm{C} / \mathrm{N}$ & $\mathrm{P}$ & $\mathrm{K}$ & $\mathrm{Ca}$ & $\mathrm{Mg}$ & $\mathrm{Na}$ & CEC & LM & LT & BLT \\
\hline & -0.39 & 0.08 & -0.3 & 0.27 & -0.1 & -0.18 & -0.44 & 0.31 & 0.18 & -0.08 & 0.28 & -0.47 & -0.27 \\
\hline
\end{tabular}

\section{Discussion}

\subsection{Litter Quality}

This study showed that some variables of initial litter chemistry of studied species (SS) which was consist of three native species/NS (mahang, geronggang and skubung) and one exotic species/ES (krassikarpa) were significantly different $(\mathrm{p}<0.05)$. However, in general all SS had similar litter quality, based on the magnitude of total N, total P, lignin, C/N, Lignin/N. The litter quality of all SS were low due to had content of $\mathrm{N}<2.5 \%$, $\mathrm{P}$ $<0.25 \%, C / N>30$ and lignin $>28 \%$ (Prescott 2005; Boyd 2009; Partey et al. 2011).

Based on some previous studies, the comparison of nutrient content in the initial litter between NS and some other tree species of tropical forest presented different results, depending on the elements. Total $\mathrm{K}$ and $P$ in the litter of all NS were higher than those in litter of Koompassia malaccensis, Shorea uliginosa, and mixed tropical peat forest tree species (Sulistiyanto et al. 2005; Ong et al. 2017). However, leaf litter of all NS in present study in general had lower $\mathrm{N}$ content than that in most of native species of tropical peat swamp forest, despite its value was in the range $(0.8-1.78)$ (Sulistiyanto et al. 2005; Ong et al. 2017; Ichie et al. 2019)

Lignin content in the litter of all NS in present study (36.1-39.2\%) was higher than that in the range of content lignin in other native tree species of peat swamp forest (3.8-35.8\%) (Hoyos-Santillan et al. 2015; Ichie et al. 2019) also than that in the average of broadleaves (29.26\%) and coniferous (21.57\%) (Rahman et al. 2013). In different ecosystem with wider scale, lignin content of leaf litter of beech (36\%) in temperate forest were the closest to lignin content in the NS (Kara et al. 2014). For polyphenol, the content in NS litter was less than that in some macaranga species litter (Lim et al. 2014).

\subsection{Micro-environment for Decomposition}

We observed the soil properties after 2.5 years of the plantation of the three NS and one ES. For the peatland ecosystem, the soil properties under 2.5 years old of NS was similar to soil properties of critically degraded peatland, drained forest peatland, agricultural peatland, peat forest that was convert to oil palm and Acacia spp. estate (Husnain et al. 2017; Yondra and Wawan 2017; Agus et al. 2020). At the tropical ecosystem, lower temperature and higher moister is better microclimate for decomposition. Therefore, the microclimate under NS in this study was better than that in agriculture peatland, similar to drained degraded and re-growing forest, but not better yet than that in natural peat swamp forest (Astiani et al. 2017; Jaya et al. 2018).

\subsection{Rate of Decomposition and Its Nutrient Release}

Decomposition rate of leaf litter of all NS in present study was slow ( $\mathrm{k}<1.8$ and $\mathrm{t}_{50}>0.4$ years), based on the classification of (Petersen and Cummins 1974), but it was higher than that of other tree species of tropical peat swamp forest $(0.25-0.81)$ (Table 8$)$. This slow decomposition confirmed that the decomposition of leaf litter of native tree species in tropical PSFs was relatively retarded. However, this phenomenon could not be generalized yet for all native tree species of PSFs, due to the decomposition studies in present and several previous studies were done in the pioneer species. Therefore, in term for whole native species of PSFs further research in non-pioneer tree species is required.

In term of decomposition in tropical tree species; the decomposition rate of all NS was relatively comparable with that of Acacia mangium and A. auriculiformis in Mount Forest; lower than that of teak, Acacia nilotica 
Table 8. Decomposition rate constant (k) across tropical tree species

\begin{tabular}{|c|c|c|c|}
\hline Species & $\mathrm{k}\left(\right.$ year $\left.^{-1}\right)$ & Site & References \\
\hline Campnosperm acoriaceum & 0.50 & $\begin{array}{l}\text { Tropical peat swamp forest, } \\
\text { Malaysia }\end{array}$ & (Yule and Gomez 2009) \\
\hline Mixed species & $0.60-0.81$ & $\begin{array}{l}\text { Mixed and low pole swamp } \\
\text { forest, Kalimantan, } \\
\text { Indonesia }\end{array}$ & (Sulistiyanto et al. 2005) \\
\hline $\begin{array}{l}\text { Calophyllum canum, Combretocarphus rotundatus } \\
\text { and Cratoxylum glaucum }\end{array}$ & $0.25-0.62$ & $\begin{array}{l}\text { Natural and post fire } \\
\text { peat swamp forest, } \\
\text { Kalimantan, Indonesia }\end{array}$ & (Rahajoe et al.2005) \\
\hline $\begin{array}{l}\text { Macaranga spp., Shorea spp., Artocarpus spp., } \\
\text { Dipterocarpus geniculatus }\end{array}$ & $0.38-2.36$ & $\begin{array}{l}\text { Tropical rain forest, } \\
\text { Serawak, Malaysia }\end{array}$ & (Hirobe et al. 2004) \\
\hline $\begin{array}{l}\text { Rhizophora racemosa, } R \text {. mucronata, } R \text {. apiculata and } \\
\text { Avicennia marina }\end{array}$ & $1.64-4.5$ & $\begin{array}{l}\text { Mangrove forest in Aceh, } \\
\text { Banten, Indonesia and } \\
\text { Costa Rica }\end{array}$ & $\begin{array}{l}\text { (Dewiyanti et al. 2019; } \\
\quad \text { Loría-Naranjo et al. } 2019 \\
\text { Siska et al. 2016) }\end{array}$ \\
\hline Juniperusprocera, Oleaeuropaea and Carissa edulis & $0.09-0.24$ & $\begin{array}{l}\text { Dry Afromontane forest, } \\
\text { Ethiopia }\end{array}$ & (Birhane et al. 2019) \\
\hline Acacia mangium and A. auriculiformis & $1.12-1.27$ & $\begin{array}{l}\text { Mount makiling forest, } \\
\text { South Central Luzon, } \\
\text { Philippines }\end{array}$ & (Lee and Woo 2012) \\
\hline Teak, Acacia nilotica, Eucalyptus sp. & $1.7-3.0$ & $\begin{array}{l}\text { Coromandel Coast, } \\
\text { Puducherry, India }\end{array}$ & $\begin{array}{l}\text { (Swarnalatha and Reddy } \\
\text { 2011) }\end{array}$ \\
\hline Pinus massoniana & 0.80 & $\begin{array}{l}\text { Pioneer masson pine forest, } \\
\text { tropical forest, Shouthern } \\
\text { China }\end{array}$ & (Chen et al. 2014) \\
\hline
\end{tabular}

and Eucalyptus sp. in Coromandel coast and also than that of mangrove tree species in Indonesia and Costa Rica; higher than that of dry afromontane tree species and Pinus massoniana in Pioneer masson pine forest; and within the litter decomposition rate range of tropical rain and wet forest tree species (Table 8).

Despite the decomposition rate of all NS was retarded, but after 4 month incubation, the release of $\mathrm{P}(>70 \%$, ) and $\mathrm{K}(>80 \%)$ from leaf litter decomposition were fast. The relatively fast of $P$ and $K$ release in present study was suggested relate to the moist condition of litter during the study period. As the result showed before, litter of all SS had high moister during decomposition study. Moist environment is the ideal condition for leach and decay $\mathrm{P}$ and $\mathrm{K}$ of litter. Litter $\mathrm{P}$ in $\mathrm{PO}^{-3}$ form was eased to decay and leach (Haitao et al. 2007), while $\mathrm{K}$ is the most mobile element, exist in ionic form and relatively not associated with plant structure thus was easiest to remove from litter, particularly by leaching (Berg and Mcclaugherty 2014).

The immobilization of $\mathrm{N}$ in all SS was related to the low quality of litter, especially with low $\mathrm{N}$ and high $\mathrm{C} / \mathrm{N}$ quotient. The $\mathrm{N}$ content in all SS litters were less than $1 \%$ and its $\mathrm{N}$ generally was not met with decomposer requirement, and would drive decomposer to acquired $\mathrm{N}$ from around environment. This process was expressed by the existing of mycelium on the litter (Figure 4). Furthermore, as shown before, the value of $\mathrm{C} / \mathrm{N}$ in initial litter of all SS was high and more than 25 . This high $\mathrm{C} / \mathrm{N}$ theoretically could have lead to $\mathrm{N}$ immobilization (Pei et al. 2019).

\subsection{The Influencing Factor on Decomposition}

The study did not find the variables of litter quality and microenvironment which had significant correlation ( $p<0.05$ ) with decomposition rate. As the result, based on correlation analysis only, our study did not found the most influencing factor in decomposition of tree studied species. However, (Prescott 2005) reported that lignin would be the determinant factor of decomposition on the litter that had lignin more than $28 \%$, but the correlation might not be significant due to rate decomposition in studied species was relatively similar in slow rate. This statement met to our study condition, which lignin content in all studied species was similar high (lignin $>28 \%$ ) and decomposition rate in all species also was similar slow. According to those facts, the present study suggested that lignin was the 
main factor that driven slow decomposition in all SS (NS and ES). For further confirmation of this suggestion, the study collected the couple data of lignin-k from other studies in relatively wider variation (Hirobe et al. 2004; Aprianis 2011), then combines with the couple lignin-k data in present study for regression analysis. Result of this regression analysis showed that lignin had negative effect on decomposition rate ( $\mathrm{k})$, strongly $(\mathrm{R} 2=0.65)$ and significantly $(\mathrm{p}<0.05)$, thus supported to the suggestion (Figure 3 ). Theoretically, this negative effect on decomposition due to the chemical structure of lignin is more complex and heterogeneous lead to not easier to degrade than other chemical component of litter (Jex et al. 2014).

Our study was undertaken at drained peatland, thus we suggested that the soil decomposer was not the constraint factor of decomposition. Despite soil microorganism parameter in the study specifically was not observed, the visualization of litter in the

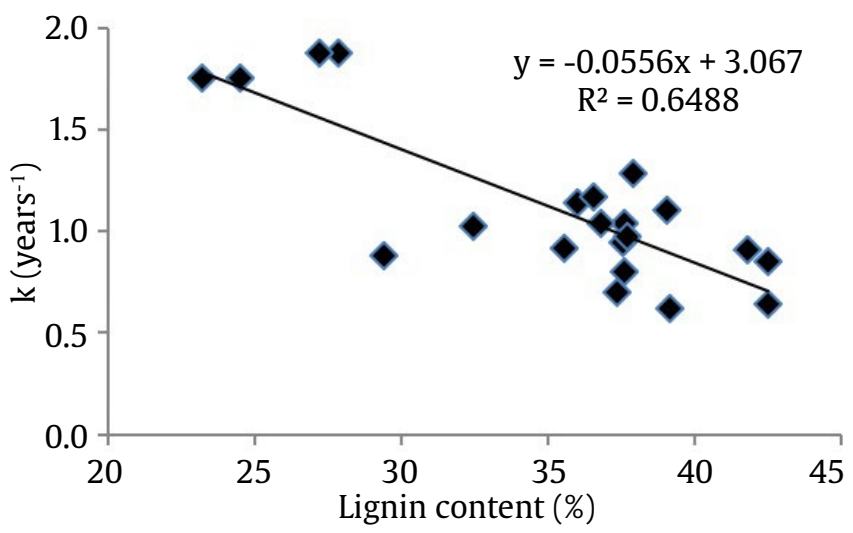

Figure 3. Regression between $\mathrm{k}$ and lignin content based on the combination data of present and previous study (Hirobe et al. 2004; Aprianis 2011)

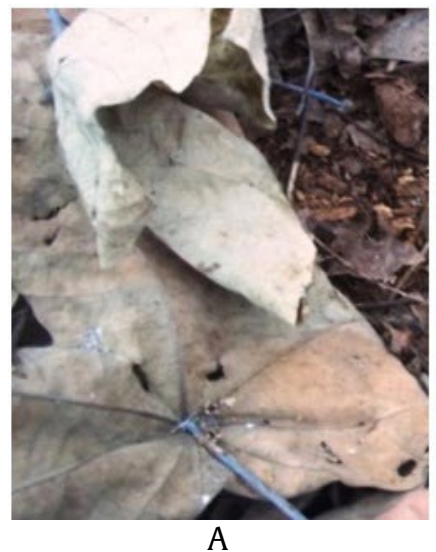

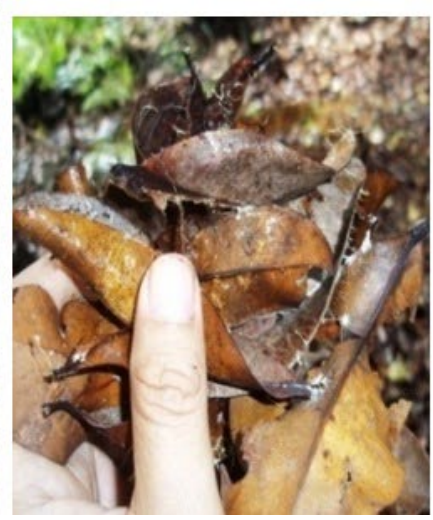

B
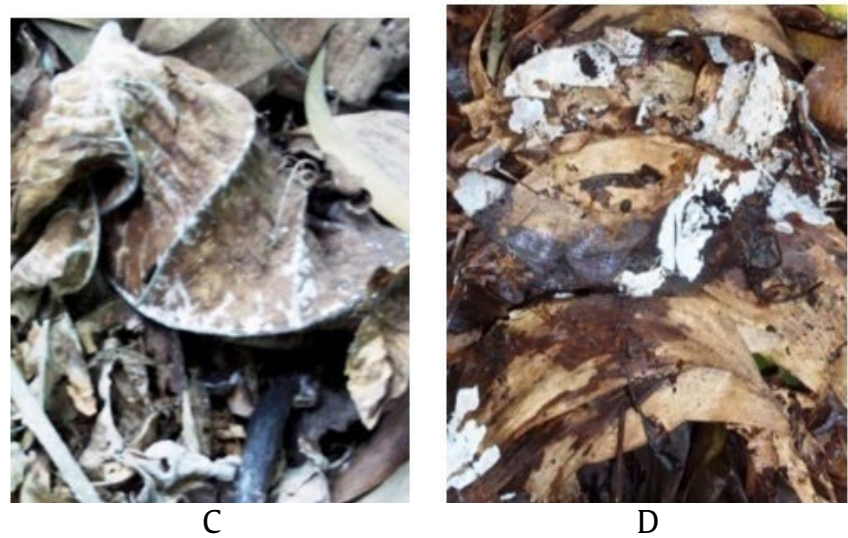

D field shown the existing of decomposer via the sign in mycelium form (Figure 4). This visualization synchronized with (Yule 2010) who reported that the microorganism in peatland was relatively diverse, including the decomposer organisms.

In conclusion, all native tree species of Macaranga pruinosa ,Cratoxylum arborescens, and Macaranga gigantea and also the exotic species of Acacia crassicarpa had similar litter quality. The litter quality of all studied species were low quality, particularly were expressed by the low $\mathrm{P}$ and $\mathrm{N}$ content, and also high lignin content. The micro-environment (soil and microclimate) under the stand of all studied species also were similar. These similarities lead the similarities of decomposition and nutrient release rate in all studied species. The decomposition rates of all studied species were slow. However, the nutrient release of $\mathrm{P}$ and $\mathrm{K}$ were fast release, while $\mathrm{N}$ was immobilized. Based on this decomposition trait, the three native species could be classified in one group and also similar with the group of the pioneer species of peat swamp forest and some acacia species. Among factors that can influence the decomposition, the presence of high lignin was the main factor that caused the slow decomposition in all studied species. For the purpose of the establishment of plantation forest which required fertile land in long term, due to nutrient content in litter was low and also $\mathrm{N}$ was immobilized, the mixed plantation with other species that had good litter quality or with some $\mathrm{N}$-fixing tree species more recommended. For peatland restoration, the slow decomposition of all native species can act as carbon sink, but could lead to the abundance of litter at peatland surface and has possibility to become fuel. Therefore, for this purpose

Figure 4. Mycelium on the litter of studied species $(A=$ mahang, $B=$ geronggang, $C=$ skubung, and $D=$ krassikarpa $)$ 
the management to maintain tree density, water table and soil/litter moister must be noticed.

\section{Acknowledgements}

We would like to thank the Ministry of Environment and Forestry for financial and a lot of valuable supports, Mr. Dahlan for providing land, Mr. Arifin and Sunarto for valuable technical assistance. We also would like to thank Dr. Haryono Supriyo for valuable supervision. This work also supported by the Research and Development Division of PT. RAPP.

\section{References}

Agus, C., Ilfana, Z., Azmi, F., Rachmanadi, D., Wulandari, D., Santosa, P., .. . Lestari, T., 2020. The effect of tropical peat land-use changes on plant diversity and soil properties. International Journal of Environmental Science and Technology. 17, 1703-1712. https://doi. org/10.1007/s13762-019-02579-X

Aponte, C., García, L.V., Maranon, T., 2012. Tree species effect on litter decomposition and nutrient release in mediterranean oak forests changes over time. Ecosystems. 15, 1204-1218. https://doi.org/10.1007/ s10021-012-9577-4

Aprianis, Y., 2011. Litterfall and decomposition rate of Acacia crassicarpa A. Cunn. in PT. Arara Abadi. Tekno Hutan Tanaman. 4. 41- 47.

Astiani, D., Burhanuddin, B., Curran, L.M., Mujiman, M., Salim, R., 2017. Effects of drainage ditches on water table level, soil conditions and tree growth of degraded peatland forests in West Kalimantan. Indonesian Journal of Forestry Research. 4, 15-25. https://doi. org/10.20886/ijfr.2017.4.1.15-25

Attignon, S.E., Weibel, D., Lachat, T., Sinsin, B., Nagel, P. Peveling, R., 2004. Leaf litter breakdown in natural and plantation forests of the Lama forest reserve in Benin. Applied Soil Ecology. 27, 109-124. https://doi. org/10.1016/j.apsoil.2004.05.003

Berg, B., Mcclaugherty, C., 2014. Plant Litter Decomposition, third ed. Springer, Berlin. https://doi.org/10.1007/9783-642-38821-7

Birhane, E., Desalegn, T., Kebede, F., Giday, K., Hishe, H., Hadgu, K.M., 2019. In situ leaf litter production, decomposition and nutrient release of dry Afromontane trees. East African Agricultural and Forestry Journal. 83, 176-190. https://doi.org/10.1080/00128325.2019.1598060

Boyd, C.E., 2009. Carbon: nitrogen ratio management. Global aquaculture advocate.

Boyle, J.R., 2005. Forest Soil. in: Hillel, D. (Eds.), Encyclopedia of Soils in the Environment. Elsevier Ltd, New York. pp. 73-79. https://doi.org/10.1016/B0-12-3485304/00033-3

Charles, D., 2019. Scientists on Indonesia's polluting hazecontrolling the peatland fire is a matter of law and order. Available at: https://forestsnews.cifor. org/62105/scientists-on-indonesias-pollutinghaze?fnl=en. [Date accessed: 23 November 2021]

Chen, H., Gurmesa, G.A., Liu, L., Zhang, T., Fu, S., Liu, Z., .. . Mo, J., 2014. Effects of litter manipulation on litter decomposition in a successional gradients of tropical forests in southern China. PLoS One. 9, e99018. https:// doi.org/10.1371/journal.pone.0099018

Dale, S.E., Turner, B.L., Bardgett, R.D., 2015. Isolating the effects of precipitation, soil conditions, and litter quality on leaf litter decomposition in lowland tropical forests. Plant and soil. 394, 225-238. https://doi.org/10.1007/ s11104-015-2511-8
Das, C., Mondal, N.K., 2016. Litterfall, decomposition and nutrient release of Shorea robusta and Tectona grandis in a sub-tropical forest of West Bengal, Eastern India. Journal of forestry research. 27, 1055-1065. https://doi. org/10.1007/s11676-016-0208-3

Dewiyanti, I., Nurfadillah, N., Setiawati, T., Yanti, F., Elrahimi, S., 2019. Litter production and decomposition of mangrove in the Northern Coast of Aceh Besar district, Aceh province. Conf. Ser.: Mater. Sci. Eng. 567, 012025. https://doi.org/10.1088/1757-899X/567/1/012025

Gultom, K., Utomo, T.C., Farabi, N., 2016. Sekuritisasi Kabut Asap Di Singapura Tahun 1997-2014. Journal of International Relations. 2, 33-43. https://doi. org/10.14710/ip.v1i2.14288

Guo, J., Wang, G., Wu, Y., Geng, Q., Cao, F., 2019. Leaf litter and crop residue decomposition in ginkgo agroforestry systems in eastern China: soil fauna diversity and abundance, microbial biomass and nutrient release. Journal of forestry research. 30, 1895-1902. https:// doi.org/10.1007/s11676-018-0758-7

Haitao, W., Xianguo, L., Qing, Y., Ming, J., Shouzheng, T., 2007. Early-stage litter decomposition and its influencing factors in the wetland of the Sanjiang Plain, China. Acta Ecologica Sinica. 27, 4027-4035. https://doi. org/10.1016/S1872-2032(07)60088-2

Hirobe, M., Sabang, J., Bhatta, B. K., Takeda, H., 2004. Leaflitter decomposition of 15 tree species in a lowland tropical rain forest in Sarawak: decomposition rates and initial litter chemistry. Journal of Forest Research. 9, 341-346. https://doi.org/10.1007/s10310-004$0087-\mathrm{X}$

Hoyos-Santillan, J., Lomax, B.H., Large, D., Turner, B.L., Boom, A., Lopez, O.R., Sjögersten, S., 2015. Getting to the root of the problem: litter decomposition and peat formation in lowland Neotropical peatlands. Biogeochemistry, 126, 115-129. https://doi.org/10.1007/s10533-0150147-7

Husnain, Sipahutar, I. A., Purnomo, J., Widyanto, H., 2017. $\mathrm{CO}_{2}$ Emissions from tropical peat soil affected by fertilization. Journal of Tropical Soils. 22, 1-9. https:// doi.org/10.5400/jts.2017.v22i1.1-9

Husnain, H., Wigena, I.P., Dariah, A., Marwanto, S., Setyanto, P., Agus, F., 2014. CO emissions from tropical drained peat in Sumatra, Indonesia. Mitigation and adaptation strategies for global change. 19, 845-862. https://doi. org/10.1007/s11027-014-9550-y

Ichie, T., Yoneyama, A., Hashimoto, T., Tanaka-Oda, A., Kusin, K., Kenzo, T., 2019. Drainage effects on leaf traits of trees in tropical peat swamp forests in Central Kalimantan, Indonesia. Tropics, 28, 1-11. https://doi. org/10.3759/tropics.MS18-12

Jaya, A., Inoue, T., Limin, S. H., Darung, U., Banuwa, I.S., 2018. Microclimate of developed peatland of the mega rice project in Central Kalimantan. Journal of Tropical Soils, 15, 63-71. https://doi.org/10.5400/jts.2010.v15i1.6371

Jex, C.N., Pate, G.H., Blyth, A.J., Spencer, R.G., Hernes, P.J., Khan, S. J., Baker, A. 2014. Lignin biogeochemistry: from modern processes to Quaternary archives. Quaternary Science Reviews, 87, 46-59. https://doi. org/10.1016/j.quascirev.2013.12.028

Junaedi, A. 2018. Growth performance of three native tree species for pulpwood plantation in drained peatland of Pelalawan District, Riau. Indonesian Journal of Forestry Research, 5, 119-132. https://doi. org/10.20886/ijfr.2018.5.2.119-132

Junaedi, A., Hardiwinoto, S., Supriyo, H., Mindawati, N. 2020. Litter productivity and leaf litter nutrient return of three native tree species in drained tropical peatland, Riau-Indonesia. IOP Conf. Ser.: Earth Environ. Sci. 533, 012007. https://doi.org/10.1088/1755$1315 / 533 / 1 / 012007$ 
Kara, O., Bolat, I., Cakıroglu, K., Senturk, M., 2014. Litter decomposition and microbial biomass in temperate forests in Northwestern Turkey. Journal of soil science and plant nutrition, $14,31-41$.

Lalramliani, C., Lalnunzira, C., Tripathi, S., 2016. Litter decomposition and nutrient release pattern in two nitrogen fixing shrubs (Flemingia macrophylla and Tephrosia candida) growing in SALT farm in Lunglei district of Mizoram. Science Vision. 16, 106-112.

Lee, Y.K., Woo, S.Y., 2012. Changes in litter, decomposition, nitrogen mineralization and microclimate in Acacia mangium and Acacia auriculiformis plantation in Mount Makiling, Philippines. International Journal of Physical Sciences. 7, 1976-1985. https://doi. org/10.5897/IJPS11.846

Lim, T.Y., Lim, Y.Y., Yule, C.M., 2014. Bioactivity of leaves of Macaranga species in tropical peat swamp and nonpeat swamp environments. Journal of Tropical Forest Science. 134-141.

Löf, M., Madsen, P., Metslaid, M., Witzell, J., Jacobs, D.F., 2019. Restoring forests: regeneration and ecosystem function for the future. New Forests. 50, 139-151. https://doi.org/10.1007/s11056-019-09713-0

Loría-Naranjo, M., Sibaja-Cordero, J.A., Cortés, J., 2019. Mangrove leaf litter decomposition in a seasonal tropical environment. Journal of Coastal Research 35, 122-129. https://doi.org/10.2112/ JCOASTRES-D-17-00095.1

Miettinen, J., Liew, S.C., 2010. Status of peatland degradation and development in Sumatra and Kalimantan. Ambio, 39, 394-401. https://doi.org/10.1007/s13280-0100051-2

Nurulita, Y., Adetutu, E.M., Gunawan, H., Zul, D., Ball, A.S., 2016. Restoration of tropical peat soils: the application of soil microbiology for monitoring the success of the restoration process. Agriculture, Ecosystems and Environment. 216, 293-303. https://doi.org/10.1016/j. agee.2015.09.031

Olson, J. 1963. Energy storage and the balance of producers and consumers in terrestrial ecosystems. Ecology, 44, 322-331. https://doi.org/10.2307/1932179

Ong, C.S., Juan, J.C., Yule, C.M., 2017. The contribution of leaching to nutrient release from leaf litter of two emergent tree species in a Malaysian tropical peat swamp forest. Hydrobiologia. 794, 125-137. https:// doi.org/10.1007/s10750-017-3086-6

Partey, S., Quashie-Sam, S., Thevathasan, N., Gordon, A., 2011. Decomposition and nutrient release patterns of the leaf biomass of the wild sunflower (Tithonia diversifolia): a comparative study with four leguminous agroforestry species. Agroforestry Systems, 81, 123-134. https://doi.org/10.1007/s10457010-9360-5

Pei, G., Liu, J., Peng, B., Gao, D., Wang, C., Dai, W., .. . Bai, E., 2019. Nitrogen, lignin, $\mathrm{C} / \mathrm{N}$ as important regulators of gross nitrogen release and immobilization during litter decomposition in a temperate forest ecosystem. Forest Ecology and Management. 440, 61-69. https:// doi.org/10.1016/j.foreco.2019.03.001

Peng, Y., Yang, W., Yue, K., Tan, B., Wu, F. 2019. Impacts of soil fauna on nitrogen and phosphorus release during litter decomposition were differently controlled by plant species and ecosystem type. Journal of forestry research.30, 921-930. https://doi.org/10.1007/s11676$018-0664-z$

Penner, J.F., Frank, D.A. 2019. Litter decomposition in Yellowstone grasslands: the roles of large herbivores, litter quality, and climate. Ecosystems. 22, 929-937. https://doi.org/10.1007/s10021-018-0310-9
Petersen, R.C., Cummins, K.W., 1974. Leaf processing in a woodland stream. Freshwater biology. 4, 343-368. https://doi.org/10.1111/j.1365-2427.1974.tb00103.x

Petraglia, A., Cacciatori, C., Chelli, S., Fenu, G., Calderisi, G., Gargano, D., Abeli, T., Orsenigo, S., Carbognani, M., 2019. Litter decomposition: effects of temperature driven by soil moisture and vegetation type. Plant and Soil, 435, 187-200. https://doi.org/10.1007/s11104018-3889-X

Prescott, C., 2005. Decomposition and mineralization of nutrients from litter and humus. In: Nutrient acquisition by plants Vol 181. Springer, Berlin. pp. 1541.

Rahajoe, J.S., Laode, A., Simbolon, H., Muhidin, A., 2005 Technical Report: Biomass Production and Annual Variation of Dominant Tree Species and the Litter Decomposition in Natural Peat Swamp Forest and Post Fire at Kelampangan, Central Kalimantan (Report No. 1907-4905). Indonesian Institute of Sciences, Bogor. pp. 196-2003.

Rahman, M.M., Tsukamoto, J., Rahman, M.M., Yoneyama, A., Mostafa, K.M., 2013. Lignin and its effects on litter decomposition in forest ecosystems. Chemistry and Ecology. 29, 540-553. https://doi.org/10.1080/02757 540.2013 .790380

Setyawati, W., Suwarsono., 2018. Carbon emission from peat fire in 2015. IOP Conf. Ser.: Earth Environ. Sci. 166012041 https://doi.org/10.1088/1755-1315/166/1/012041

Siska, F., Sulistijorini, S., Kusmana, C., 2016. Litter Decomposition Rate of Avicennia marina and Rhizophora apiculata in Pulau Dua Nature Reserve, Banten. Journal of Tropical Life Science. 6, 91-96. https://doi.org/10.11594/jtls.06.02.05

Suhartati, Rahmayanti, S., Junaedi, A., Nurrohman, E. 2012. Distribution and site requirements of several alternative pulpwood species in Riau. in: Mindawati, N., Pamoengkas, P., Sutisna, U., (Eds.). Forest Research and Development Agency, Jakarta.

Sulistiyanto, Y., Rieley, J., Limin, S., 2005. Laju dekomposisi dan pelepasan hara dari serasah pada dua sub-tipe hutan rawa gambut di Kalimantan Tengah. Jurnal Manajemen Hutan Tropika. 11, 1-14.

Swarnalatha, B., Reddy, M.V. 2011. Leaf litter breakdown and nutrient release in three tree plantations compared with a natural degraded forest on the coromandel coast (Puducherry, India). Ecotropica. 17, 39-51.

Versini, A., Zeller, B., Derrien, D., Mazoumbou, J.C., Mareschal L., Saint-André, L., . . . Laclau, J.P., 2014. The role of harvest residues to sustain tree growth and soil nitrogen stocks in a tropical Eucalyptus plantation. Plant and soil. 376, 245-260. https://doi.org/10.1007/ s11104-013-1963-y

Worldbank., 2019. Indonesia Economic Quarterly, June 2019: Oceans of Opportunity: World Bank.

Wright, E., Black, C., Cheesman, A., Turner, B. L., Sjögersten, S., 2013. Impact of simulated changes in water table depth on ex situ decomposition of leaf litter from a neotropical peatland. Wetlands. 33, 217-226. https:// doi.org/10.1007/s13157-012-0369-6

Yondra, Y., Wawan, N., 2017. Chemical properties study of peatland on various landuse. Agric, 29, 103-112. https://doi.org/10.24246/agric.2017.v29.i2.p103-112

Yule, C.M., 2010. Loss of biodiversity and ecosystem functioning in Indo-Malayan peat swamp forests. Biodiversity and conservation, 19, 393-409. https:// doi.org/10.1007/s10531-008-9510-5

Yule, C.M., Gomez, L.N., 2009. Leaf litter decomposition in a tropical peat swamp forest in Peninsular Malaysia. Wetlands Ecology and Management. 17, 231-241. https://doi.org/10.1007/s11273-008-9103-9 